\title{
Political Psychology
}

\section{The Mistreatment of My People: Victimization by Proxy and Behavioral Intentions to Commit Violence Among Muslims in Denmark}

\author{
Milan Obaidi \\ Uppsala University \\ Robin Bergh \\ Harvard University \\ Jim Sidanius \\ Harvard University \\ Lotte Thomsen \\ University of Oslo \\ University of Aarhus
}

\begin{abstract}
Islamist extremism is often explained by the suffering endured by Muslims in Islamic countries as a result of Western-led wars. However, many terrorist attacks have been carried out by European Muslims with no personal experiences of war. Across two studies among Danish Muslims, we tested if what we call "victimization-by-proxy processes" motivate behavioral intentions to commit acts of violence. We used Muslim identification, perceived injustice of Western foreign policies, and group-based anger to predict violent and nonviolent behavioral intentions. More importantly, we compared path models of Danish Muslims from conflict zones with those without direct personal experience of Western-led occupation. We found similar effects among the participants in each category, that is, vicarious psychological responses mimicked those of personally experienced adversity. In fact, participants born in Western Europe were, on average, more strongly identified with Muslims, more likely to perceive Western foreign policy as more unjust, reported greater group-based anger, and were more inclined to help Muslims both by nonviolent and violent means.
\end{abstract}

KEY WORDS: extremism, victimization by proxy, social identity, group-based injustice and emotion, Western foreign policy

Documents from the inner circles of the Islamic State surfaced on April 18, 2015 in one of Europe's biggest newspapers. The article in der Spiegel outlined "the blueprint for this state" (Reuter, 2015). One strategy described in these documents was to use inexperienced foreign fighters alongside veteran Chechens and Uzbeks fighters in the civil wars in Syria and Iraq rather than primarily relying 
on domestic fighters. This strategy presents a perplexing reality to scholars and terrorism experts because many have argued that Islamic extremism results from the experience of direct exposure to Western-led military interventions/occupation/drone attacks and foreign policies in Muslim countries (e.g., Nesser, 2006; Pape, 2003, 2006; see also Sidanius, Kteily, Levin, Pratto, \& Obaidi, 2015). Presumably, however, the Islamic State did not consider it necessary that their fighters had personal experience from wars or Western occupation. Instead, they simply imported extremism that had sprung to life elsewhere, for example, within the West (where so-called homegrown terrorism has been an issue for over a decade; see Roy, 2004). Here, we demonstrate the effects of what we refer to as victimization-by-proxy processes on such homegrown Islamic extremism and behavioral intentions to commit violence in Europe. We define extremism as encompassing behaviors, ideas, intentions, attitudes, and values that are not in accordance with the norms of the society, such as rejecting the state monopoly on violence (and the promotion of alternative forms of violence) within a democracy (for a comprehensive definition of extremism and other related concepts, see Schmid, 2013).

When Islamic extremists in the West provide reasons for their attitudes or actions, they often refer to the perceived wrongdoings against Muslims in the Islamic world at the hands of the West. Following the July 7, 2005 London bombing, for example, Mohammad Sidique Kahn, the ringleader, claimed that Great Britain's “democratically elected governments continuously perpetrate atrocities against my people all over the world. ... Until you stop the bombing, gassing, imprisonment and torture of my people we will not stop this fight" (BBC News, 2005). Mohammad Sidique Kahn, like many like-minded Islamic extremists, was born and raised in Europe without any direct experience of Western foreign policy. Khosrokhavar (2005) describes this in terms of "humiliation-by-proxy." Lickel, Miller, Stenstrom, Denson, and Schmader (2006) similarly argued that vicarious retaliation is a phenomenon where a "member of a group commits an act of aggression toward the members of an outgroup for an assault or provocation that had no personal consequences for him or her but which did harm a fellow ingroup member" (p. 372). The present work also stresses vicarious processes, but we broaden this argument in a number of ways. First, not all acts in defense of a group are retaliatory or violent, so we anchored our inquiry within the broader collective action literature to also encompass nonviolent outcomes (Wright, Taylor, \& Moghaddam, 1990). Second, based on combined insights from the collective action, social identity, and intergroup emotion literatures, we did not limit our focus to feelings of humiliation, but we rather focused on interplay of group identification, perceived injustice, and group-based anger (Smith, 1993).

Our victimization-by-proxy argument, as promoted here, rests on three interrelated ideas. The first is based on the social identity literature (Tajfel \& Turner, 1979), suggesting that people not only think, feel, and act on the basis of their individual circumstances, but also the circumstances of groups to which they belong. Second, we suggest that the foreign policies of Western countries are not the only triggers for seeing the world in terms of "us" and "them" but also a driving force of group mobilization among Muslims, native and war-zone-born alike. As Pape (2003) argues, the "deep anger [among Western born Muslims] at the use of foreign combat forces to suppress national selfdetermination by kindred groups is sufficient to inspire self-sacrifice even when personal motives for revenge are completely absent" (p. 1). Third, we argue that different group-related events trigger emotional and behavioral reactions that largely mirror the expected consequences as if people had experienced the events personally (Mackie, Devos, \& Smith, 2002). We begin by briefly reviewing the extant literatures as related to each of these ideas.

Drawing on the collective action model of social identity (SIMCA; van Zomeren, Postmes, and Spears, 2008), we apply the social identity analysis to studies of violent and nonviolent support of groups. Social identity theory predicts that identification with disadvantaged groups is a predictor of collective action (Ellemers, 1993). Expanding these analyses, self-categorization theory (Turner, Hogg, Oakes, Reicher, \& Wetherell, 1987) describes the cognitive processes and consequences associated with social identity salience or, more informally, a "group mode" of thinking. The self and 
fellow group members are then perceived as a unified entity_- "us" (Turner et al., 1987)—and group identification will subsequently influence individuals' reactions to the group (Tajfel \& Turner, 1979).

Now consider the case of Muslim identity in the West. Many scholars discuss a developing "clash of civilizations" between Muslims and non-Muslims (Huntington, 1993; Lewis, 1990), and from the perspective of self-categorization theory, this should make Muslim identity highly salient among members of this group. Some have also commented that the extremist ideologies propagated by Islamic extremists aim to indoctrinate Muslims into thinking similarly, in order to unite them (Loza, 2007), and to induce a sense of collective grievance and victimization (Wagemakers, 2008). Thus, when Western Muslims consider themselves as agents acting on behalf of the global Muslim community, or Muslims living under occupation (rather than acting on behalf of the Danish or Danish immigrant community, for example), Muslim identity processes should be an important contributing factor (see also Lyons-Padilla, Gelfand, Mirahmadi, Farooq, \& van Egmond, 2015). This should especially be the case for Western-born Muslims, as some suggest (e.g., Pape, 2003), because their link to the people that suffer in Muslim conflict zones rests on a global identification with Muslims worldwide or "umma," rather than on being born into the countries that suffer occupation, or more recently, drone attacks, by the West.

According to the social identity model of collective action (van Zomeren et al., 2008), Muslim group identification underlies the perception of Western countries' foreign policy because it provides the basis for the group-based perception of victimization. Once the feelings of injustice and of shared grievances within a group are triggered, it should eventually evoke corresponding group-based emotions and behavioral tendencies as a result. In this sense, Western Muslims feel threatened and victimized, not because of personal experiences, but because of the effects on groups with which they identify. According to this reasoning, a situation or event that is appraised to harm or threaten the ingroup is likely to trigger a relevant vicarious response. This focus on justice-related affect is in line with recent theorizing on intergroup emotions theory (Mackie et al., 2000).

Highlighting the ways in which people are similar to the victims of unjust treatment has been shown to lead to increased feelings of injustice, anger, and a tendency to act against the perceived perpetrators (e.g., Gordijn, Wigboldus, \& Yzerbyt, 2001; Kuppens, Yzerbyt, Dandache, Fischer, \& van der Schalk, 2013). More broadly, intergroup emotions theory suggests that appraisal of situations that affect other members of the ingroup, but not the person herself or himself, may trigger intergroup emotional and behavioral responses (Doosje et al., 1998; Mackie et al., 2000; Smith, 1993; Smith \& Mackie, 2015; Smith, Seger, \& Mackie, 2007). For example, witnessing members of the ingroup being unjustly treated leads people to respond vicariously with anger and aggression. These emotional and behavioral reactions further depend on how strongly people identify with the victims (e.g., Gordijn, Yzerbyt, Wigboldus, \& Dumont, 2006; Kuppens et al., 2013; Yzerbyt, Dumont, Wigboldus, \& Gordijn, 2003). Hence, according to the social identity and intergroup emotions literatures, group identity should strengthen the individual's perception that his or her ingroup is a target of unjust treatment, which in turn should intensify the group's emotional and behavioral reactions to such perceived injustice (Grant, 2008). Feelings of injustice and group-based emotions, in turn, should increase the individual's likelihood of participating in collective action against the transgressors (Branscombe, Ellemers, Spears, \& Doosje, 1999). It is also important to note that within the broader literature of collective action, disadvantaged groups might exhibit an array of specific protest intentions, attitudes, and behaviors as a result of perceived injustice (Wright, Taylor, \& Moghaddam, 1990). Therefore, examining factors that lead to both violent and nonviolent behavioral intentions is an important step toward advancing the theory of collective action.

\section{The Present Research}

When it comes to research on extremism and terrorism, as opposed to collective action research in other areas, the literature is rich in theory but rather poor in empirics (Silke, 2004). For example, 
even if several scholars have stressed vicarious processes in many group behaviors, including extremist violence (e.g., Pape, 2006), a fundamental prediction in this reasoning remains untested-namely that the factors motivating Muslim violence should be similar for people born and raised in the West and for those who have directly experienced Western-led military intervention in their home countries. That is, we do not solely propose a model of victimization, but we focus on directly testing if a model based on vicarious processes would mimic one based on direct experience.

In Study 1, we first tested the victimization-by-proxy argument in a path analytic framework where we compared Muslims born in Denmark with those who immigrated to Denmark from Muslim countries targeted by the foreign policy and military interventions of Western countries (such as Afghanistan, Iran, Iraq, and Pakistan-henceforth referred to as native- vs. foreign-born Muslims). Thus, our initial test was based on distinguishing places of birth (within Europe vs. in conflict zones in the Muslim world that have been the subject of Western military interventions). To the extent that the victimization-by-proxy perspective is correct, we hypothesized that a psychological model predicting violent and nonviolent intentions among Muslims in Denmark would not differ between native- and foreign-born participants. In Study 2, we sought to validate the results from Study 1 by comparing Muslims born in Europe with people known to have lived in a conflict zone at the time of a major Western intervention (the 2001 invasion in Afghanistan, led by the United States). That is, we used a more direct measure of exposure to Western foreign policy, rather than using birthplace as a proxy for experience.

We examined a model exploring violent and nonviolent behavioral intentions based on key predictors from the social identity literature (Mummendey, Kessler, Klink, \& Mielke, 1999; Simon et al., 1998), perceived injustice literature (Smith, Pettigrew, Pippin, \& Bialosiewicz, 2012), and intergroup emotions theory (Smith, 1993; Smith et al., 2007). Specifically, we modeled Muslim identification and perceived injustice (against Muslim countries by the influence of the West) as independent variables, group-based anger as a mediator, and the two types of behavioral intentions as final outcomes.

A few things are worth noting here about the model itself. First, the order of the variables in the model was meant to reflect the cumulative insights from the literatures on the causal relations between identification, cognitive appraisals, group-based emotions, and behavioral intentions (Smith, et al., 2012). Specifically, a number of studies suggest that both group identification and cognitive appraisals (e.g., perceived injustice) influence attitudes and behavioral intentions (e.g., Dumont, Yzerbyt, Wigboldus, \& Gordijn, 2003; van Zomeren et al., 2008). Research also indicates that group-based emotions mediate these effects (Gordijn et al., 2006). Second, we focus on behavioral intentions rather than attitudes or support of violence, because the former tend to be better proxies of behaviors (see De Weerd \& Klandermans, 1999; see also Ajzen \& Fishbein, 1977). Third, a growing literature suggests that there are different psychological factors associated with violent versus nonviolent group mobilization and collective action (Livingstone, Spears, Manstead, \& Bruder, 2009; Tausch et al., 2011); so our model was constructed to account for this possibility. Fourth, whereas previous research has documented somewhat different effects of group-based anger and group-based contempt, we found these two variables to be highly correlated in our samples $(r=.87)$, so we focused on anger alone, to reduce multicollinearity.

The most important question posed in this article concerned the differences versus similarities between native- and foreign-born Muslims. Thus, using a multigroup approach (native- vs. foreignborn Muslims), we directly tested whether the factors underpinning Muslim (violent and nonviolent) mobilization differed based on direct experiences from Western foreign policies and occupations. A victimization-by-proxy argument would suggest that this is not the case and that the explanatory models should be quite similar across both groups. Importantly, this is not to suggest that there are no psychological differences between these two groups, but if the model for native-born Muslims mimics the one for foreign-born Muslims, we would, at the very least, have evidence for the claim that several key predictors of extremism can operate in a vicarious fashion.

A second aim of this article was to examine potential mean differences between native and foreign-born Muslims on Muslim identification, perceived injustice, and group-based anger as well as 
violent and nonviolent behavioral intentions. From a personal experience account, it would be reasonable to expect higher levels of, for example, intergroup anger and perceived injustice among foreignborn Muslims who have directly experienced the consequences of foreign occupation. In contrast, a victimization-by-proxy position perspective would rather predict that perceived injustice, group-based emotions, and corresponding action tendencies can be elicited even when Muslims have not personally experienced Western foreign policy and military interventions (see Smith, 1993).

\section{STUDY 1}

\section{Method}

\section{Participants}

We sampled 491 (331 women) Muslims from 32 different Islam-related Facebook websites in Denmark. ${ }^{1}$ We selected these websites in such a way so as to provide demographic and ideological diversity. For example, we included websites for practicing Muslims with strong religious beliefs and adherence to traditional Islamic values but also other websites expressing more moderate and secular views of Islam. Of the total sample, 185 were born in Denmark, 225 in conflict zones, and 65 outside conflict zones (the last category of participants were excluded from further analyses; see introduction for rationale). Participants received no personal compensation for participation, but instead we paid 20 DKK (approximately \$4) to a charitable cause chosen by each participant. Respondent ages ranged from 16 to 74 years, with the majority between 18 and 34 years old (i.e., $93.6 \%$ of the total sample). Importantly, the age of these participants matches the distribution of those who join terrorist organizations in Europe (e.g., Bakker, 2006). All participants identified as either first- (56.7\%), second- (34.9\%), or third-generation (1.9\%) Muslim immigrants to Denmark. Of the total sample, $1.7 \%$ identified as being upper class, $13.1 \%$ as being upper middle class, $69.1 \%$ as being middle class, $12.5 \%$ as being lower middle class, and $3.1 \%$ as being working class.

Muslim residents in Denmark constitute a prime example of a "hidden" and "hard-to-reach" population that usually remains invisible in "standard" research (see Heckathorn, 1997). In many cases, immigrant group membership involves low visibility with strong privacy concerns (e.g., many have little trust in the sociopolitical system of their host countries and may hold uncertain legal status). Further, the media coverage of recent terrorist attacks in Europe linked to Muslims added further difficulties in the data collection. Considering these factors, the sample size was determined by the amount of data that could be collected within the time frame of six months. Statistical power is discussed under the heading, "Statistical Considerations."

\section{Measures}

The survey included measures of Muslim identification ( $\alpha$ s $>.86$, adapted from Doosje, Ellemers, $\&$ Spears, 1995), the perception of Western countries' foreign policy and military interventions ( $\alpha \mathrm{s}>.71$, based on qualitative interviews, Obaidi, 2017), violent behavioral intentions $(\alpha \mathrm{s}>.71$ adapted from Doosje et al., 2013), nonviolent behavioral intentions to defend and/or support Muslims and/or Islam $(\alpha \mathrm{s}>.78)$, and group-based anger $(\alpha \mathrm{s}>.90)$. The last two measures were adapted from Tausch et al. (2011). For detailed information about the instruments, including item content, means, standard deviations, and reliabilities for native- and foreign-born Muslims, see Table S1 in the online supporting information.

\footnotetext{
${ }^{1}$ Study 1 consists of two samples, which were collected at different time points, with different questions and populations. Our preliminary analyses showed that the results were consistent across the two samples. Therefore, we have combined the two samples, and now we describe them as one study. For the (direct) replication across the two subsamples, see the online supporting information.
} 
Table 1. Correlations Between Variables for Personal (below diagonal) Versus No Personal Experience of Western Military Interventions (above diagonal)

\begin{tabular}{|c|c|c|c|c|c|}
\hline Variables & 1 & 2 & 3 & 4 & 5 \\
\hline \multicolumn{6}{|l|}{ Study 1} \\
\hline 1. Muslim Identification & - & .48 & .39 & .18 & .40 \\
\hline 2. Perceived Injustice & .36 & - & .69 & .17 & .42 \\
\hline 3. Group-Based Anger & .45 & .71 & - & .27 & .39 \\
\hline 4. Violent Behavioral Intentions & .16 & .16 & .33 & - & .09 \\
\hline 5. Nonviolent Behavioral Intentions & .33 & .40 & .44 & .12 & - \\
\hline
\end{tabular}

Note. Correlations above .12 are significant at $p<.05$.

Given the difficulty in reaching our samples, studies included in the current article were part of a larger battery of variables, collected to answer different research questions within the same surveys. Variables not included here concerned, for example, social dominance orientation, religious fundamentalism, ethnic identification, and right-wing authoritarianism. Bivariate correlations between all focal variables for both groups are presented in Table 1 .

\section{Statistical Considerations}

In our main analyses, we used multigroup path analysis and tested the extent to which a model of violent and nonviolent behavioral intentions would differ between native- and foreign-born Muslims in Denmark. Specifically, if the model fit did not significantly deteriorate when constraining all paths to be equal for native- and foreign-born Muslims, then we would have support for the victimizationby-proxy perspective. Importantly, this is a no-difference hypothesis, but structural equation modeling (and path analysis) provides a comparably rigorous way of testing such claims. Specifically, it is well known that models with many parameters easily produce significant misfit to data (MacCallum, Browne, \& Cai, 2006). In our case, we tested for the significance for differences between the two groups for all paths in the model. Thus, we compared a model with free estimates for all paths in both groups with another model where all paths were set to be equal across groups $(9 d f, N=410)$.

The root mean square error of approximation (RMSEA) can be used for power analyses in a SEM framework and in particular to compare a nonconstrained model with a constrained (nested) alternative (MacCallum et al., 2006). For example, if the equality constraints in our case, as compared to the free model, displayed deteriorated model fit from close (RMSEA $=.05)$ to acceptable (RMSEA $=.08$ ), then the power would be .97 to detect the difference (Preacher \& Coffman, 2006). Also, if the RMSEA went from .00 to a close fit (.05), the power for this comparison would be .63 (see also MacCallum et al., 2006, for a discussion of the fact that poorly fitting models are associated with greater power). That is, if the overall difference between native- and foreign-born was big enough to produce such shifts in the RMSEA for the constrained compared to nonconstrained model (i.e., refuting our hypothesis), then we would have reasonable power to detect it. While the above fit differences are somewhat arbitrary, we also considered comparative fit index (CFI) changes of more than .01 to be nonnegligible (i.e., refuting our hypotheses), in line with conventions for (factor) model invariance testing (e.g., Cheung \& Rensvold, 2002). Finally, throughout all analysis in this article, we used the robust maximum likelihood estimator in Mplus (Muthén \& Muthén, 2012) to account for missing data $(<3 \%)$ and skewed distributions.

\section{Results}

\section{Multigroup (native- vs. foreign-born) Path Analyses}

The main question of this article was whether the psychological underpinnings of violence and nonviolence would differ depending on the experience of Western countries' foreign policy 


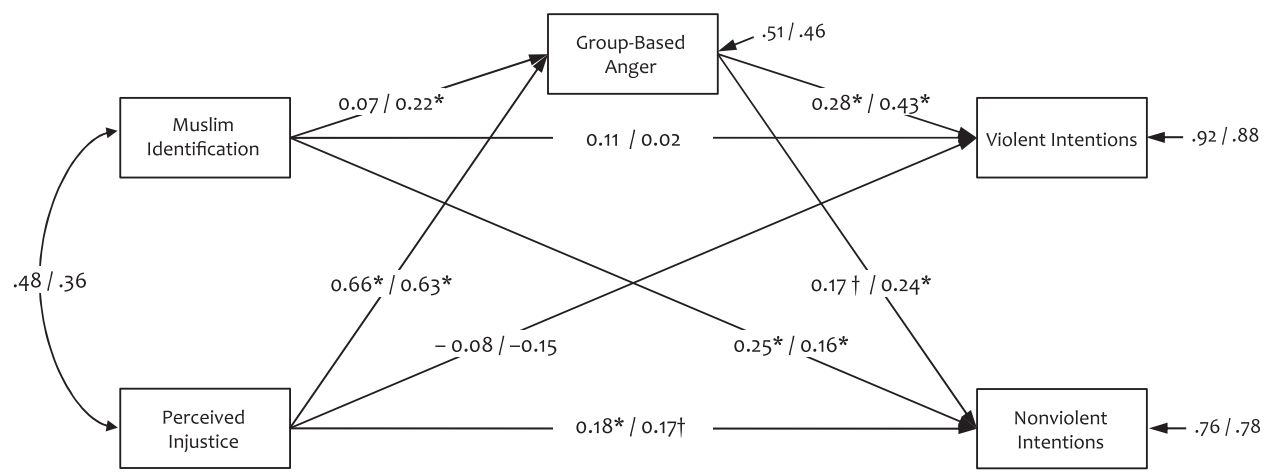

Figure 1. Standardized results of a multigroup (native- versus foreign-born) path analysis to predict violent and nonviolent intentions to defend Islam and other Muslims. $\dagger p=.05-.08 ; * p<.05$.

and military interventions in the Muslim world. To examine this question, we ran a multigroup path analysis to compare native- and foreign-born Muslims in Denmark. The standardized results from this analysis are presented in Figure 1, illustrating the associations among the variables in each of the two groups. We also tested whether these relations were robust to the introduction of demographic variables for age, gender, education, and socioeconomic status. All paths that were significant without these control variables remained as strong in this analysis $(\beta s \geq 0.16$, $p$ s $\leq .04)$.

Next, we formally tested how large the group differences were by comparing the previous (unconstrained) model with another model where all coefficients were constrained to equality for native- and foreign-born Muslims. The fit did not deteriorate when we assumed that all (unstandardized) paths were identical, $\Delta \chi^{2}(9)=5.69, p=.77$. In fact, the constrained model had excellent fit on all indices; $\chi^{2}(11)=6.40, p=.85, C F I=1.00, R M S E A=.00,90 \%$ CI $[.01, .04]$, SRMR $=.02$. This indicates that the empirical relationships in the model are not strongly influenced (above and beyond random fluctuation) by the respondents' birthplace, particularly whether they come from Muslim countries targeted by Western sanctions and military interventions or not.

Next, we examined the robustness of our results with regards to the operationalization of violent intentions. Specifically, we measured violent behavioral intentions with two items, but only one of these referred particularly to violence in defense of Muslims. Thus, we ran additional analyses where we only included the item that was directly related to violent behavioral intentions in defense of Islam/Muslims (see Table S1 in the online supporting information). The results of the path model analysis showed that all relations were close to the results in the model when using both of the items for extreme behavioral intentions ( $\beta \mathrm{s}=$ original estimate \pm 0.05$)$.

We subsequently tested the indirect effects of Muslim identification and perceived injustice (via group-based anger) on violent and nonviolent intentions among both native and foreign-born Muslims. For that purpose, we derived bootstrapped confidence intervals for these effects based on 5,000 draws. There was a marginally significant indirect effect of Muslim identification on nonviolent intentions for foreign-born Muslims $(\beta=.05,95 \%$ CI $[0.01,0.10])$, and this dropped to a nonreliable effect among native-born Muslims, $\beta=.01,95 \% \mathrm{CI}[-0.02,0.04]$. There was a similar trend for violent behavioral intentions, $(\beta=0.09,[0.04,0.15])$, and $(0.02[-0.02,0.06])$. In addition, there was an indirect effect of perceived injustice on nonviolent intentions among foreign-born participants $(\beta=0.15,95 \%$ CI $[0.05,0.25])$, and a weaker, unreliable indirect effect among native-born participants $(\beta=0.11[-0.01,0.24])$. Finally, the most noticeable indirect effects were found for perceived injustice in relation to violence, both within the 


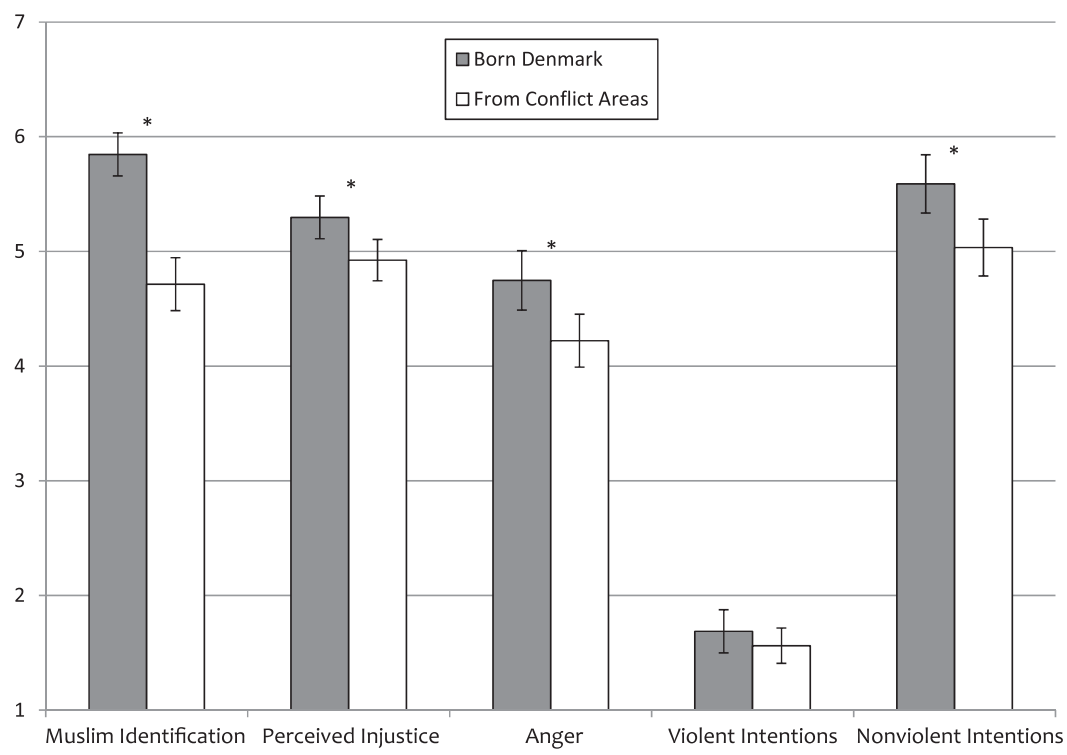

Figure 2. Mean levels of study variables for participants born in Denmark versus coming from countries targeted by military interventions by Western powers. Error bars represent $95 \%$ confidence intervals. $* p<.01$.

foreign- $(\beta=0.27,[0.14,0.39])$ and native-born groups $(\beta=0.19[0.07,0.31])$. Overall, the indirect effects were typically stronger among native-born Muslims, but as expected from the overall model results, the discrepancies were typically rather small.

\section{Mean Differences Between Native- and Foreign-Born Muslims}

Finally, we examined mean differences between native and foreign-born Muslims on all variables in our model in a series of ANOVAs (see Figure 2). Native-born participants scored higher on Muslim identification $\left(F[1,407]=53.09, \quad p<.001, \eta^{2}=.12\right)$, group-based anger $(F[1$, $\left.403]=8.99, p=.003, \eta^{2}=.02\right)$, perceived injustice $\left(F[1,406]=7,94, p=.005, \eta^{2}=.02\right)$, and nonviolent intentions $\left(F[1,404]=9,38, p=.002, \eta^{2}=.02\right)$. We found no significant difference with regards to violent behavioral intentions, $F(1,406)=1.05, p=.31, \eta^{2}=.003$, indicating that the endorsement of violent behavioral intentions did not substantially differ between native-born Muslims and foreign-born Muslims who came from countries that have been the target of Western foreign policy and military interventions.

\section{Discussion}

As an initial test of the thesis of victimization by proxy, we found support for the notion that vicarious psychological processes could explain behavioral intentions among Danish Muslims to use violence in defense of Islam and/or Muslims. The psychological processes appearing to motivate Muslim violence against the West did not differ between those coming from countries that have been the target of Western foreign policy and military interventions and those born in Denmark. Further, we also examined mean differences between native- and foreign-born Muslims, and the results showed that native-born Muslims, on average, more strongly identified with Muslims, perceived Western foreign policy as more unjust, reported greater group-based anger, and were more inclined to help Muslims by nonviolent, but not violent, means. 


\section{STUDY 2}

Study 1 showed that key psychological mechanisms in extremism operate in vicarious fashionthat is, mimic the effects of direct experience. However, one of the limitations of Study 1 is that we cannot be sure that participants born in conflicts zones count themselves as having direct personal experiences of Western foreign policies and military interventions. This is important because the entire argument of victimization by proxy rests on the idea that those who have not personally experienced Western foreign policy would be as inclined to endorse violence against the West as those who have. Therefore, in Study 2, we assessed direct personal experience of Western foreign policy to validate our results from Study 1. In Study 2, we specifically sampled Muslims coming from a country that has been the target of Western military interventions and occupation. More specifically, we concentrated on European Muslims with, versus without, experience of the 2001 U.S.- and allies-led invasion of Afghanistan. This invasion of Afghanistan has been one of the main sources of Muslim grievance, and some have argued that the invasion has led to increased terror threat towards Western societies (Nesser, 2006). For example, the ringleader of the London bombing, Mohammad Siddique Khan, noted that Denmark and Italy would be the next targets "if they do not withdraw troops from Iraq and Afghanistan" (Sciolino, 2005).

For the purpose of this study, we compared Afghan Danes who have personally experienced the 2001 invasion with those who have not. The former group emigrated from Afghanistan after the United States and its allies invaded the country in 2001, and the latter group included native-born Afghans (born and raised in Denmark) as well as Afghans who fled Afghanistan before 2001. If the victimization-by-proxy process accounts for Muslim extremism, then we should find no systematic difference between these two groups in their intentions to commit acts of violence against the West in response to the military occupation of the country.

Another aim of Study 2 was to use a more specific measure of violence in defense of Muslims and/or Islam to improve the predictability of violent behavioral intentions. To measure violent behavioral intentions, we included two new items in the current study, in addition to the two items we used in Study 1 that directly measured violent behavioral intentions in defense of Muslims and Islam (see "Measures").

\section{Method}

\section{Participants}

Study 2 was conducted in Denmark and was based on snowball sampling. We sampled 243 (113 women) Afghans living in Denmark. The data collection started in December 2013. Due to the difficulties of obtaining respondents from this population, it took over a year to complete the data collection. Of the total sample, 102 emigrated from Afghanistan after the 2001 U.S.- and allies-led invasion; 20 emigrated before, and 117 were born and raised in Denmark. Participants received 30 DKK (\$5) for participation. Respondent ages ranged from 18 to 65 years, with the majority between 20 and 30 years (i.e., $65.9 \%$ of the total sample). All participants identified as either first- (63.9\%), second- $(27.7 \%)$ or third-generation (1.3\%) Muslim immigrants in Denmark. Of the total sample, $7 \%$ identified as being upper class, $6.2 \%$ as being upper middle class, 18.9 as being middle class, $46.5 \%$ as being lower middle class, and $17 \%$ as being working class.

\section{Measures}

The survey for Study 2 included measures from Study 1 plus the two new violent behavioral intention items. These items were "I am ready to use violence to defend Islam" and "I am ready to use violence to defend other Muslims." The four-item index had excellent reliability $(\alpha=.95$; see Table S1 in the online supporting information for all items, means, standard deviations, and 
Table 2. Correlations Between Variables for Personal (below diagonal) Versus No Personal Experience of Western Military Interventions (above diagonal)

\begin{tabular}{lccccc}
\hline Variables & 1 & 2 & 3 & 4 & 5 \\
\hline 1. Muslim Identification & - & .34 & .27 & .57 & .34 \\
2. Perceived Injustice & .31 & - & .55 & .43 & .48 \\
3. Group-Based Anger & .30 & .46 & - & .56 & .48 \\
4. Violent Behavioral Intentions & .55 & .24 & .52 & - & .39 \\
5. Nonviolent Behavioral Intentions & .23 & .37 & .33 & .28 & - \\
\hline
\end{tabular}

Note. All correlations are significant at $p<.05$.

reliabilities). Bivariate correlations between all focal variables for Study 2 and for all respondents are presented in Table 2.

\section{Results}

\section{Multigroup Path Analysis for Direct Personal Experience Versus No Experience of the 2001 U.S.-Led Invasion of Afghanistan}

A multiple group path analysis was performed to examine whether the explanatory model of violent and nonviolent intentions would apply similarly to Danish-Afghan Muslims with and without direct personal experience of 2001 invasion of Afghanistan. ${ }^{2}$ We first ran a baseline model in which we allowed all relations between the variables to vary between the two groups. This model fit the empirical data well, scaled $\chi^{2}(2)=1.36, p=.51, C F I=1.00, R M S E A=.00,90 \%$ CI [.00, .16], $S R M R=.01$. The standardized coefficients from the unconstrained model are presented in Figure 3, showing the (relatively minor) variation across the two groups (see Figure 3 ). As in Study 1, we also tested whether the relations were robust to the introduction of demographic variables for age, gender, education, and socioeconomic status. With the exception of the path from Muslim identification to group-based anger, which turned marginally significant $(\beta=0.13, p=0.09)$, the remaining paths remained just as strong in this analysis $(\beta s \geq 0.18, p s \leq .04)$.

As in Study 1, we subsequently tested a model in which all relations between the variables were constrained to equality across the two groups. This model also provided excellent fit, scaled $\chi^{2}$ $(11)=7.36, p=.77, C F I=1.00, R M S E A=.00,90 \%$ CI $[.00, .07]$, SRMR $=.06$, and the difference between these models was nonsignificant, scaled $\Delta \chi^{2}(9)=6.01, p=.74$. This indicates that the relationships between the variables were consistent across the two groups, within the margins of random variation, thus providing support for the notion of victimization by proxy. Finally, to provide an exact replication of the initial results from Study 1, we ran another set of analyses where we only included the two behavioral intention items for violence that we initially used (see also instrument section). The results from these analyses showed consistent results in this study compared to Study 1, and there were no substantial differences compared to the results here with all four items (for details, see the online supporting information).

Next, we again tested the indirect effects of Muslim identification and perceived injustice (via group-based anger) on violent and nonviolent intentions among those with and without direct personal of Western foreign policy. The most noticeable indirect effects were found for perceived injustice in relation to violence, both among those with $(\beta=0.18[0.06,0.30])$, and those without $(\beta=0.21$, $[0.13,0.29])$ personal experience of western foreign policy. In addition, there was a significant indirect

\footnotetext{
${ }^{2}$ We ran additional analysis, where we excluded those Afghans who immigrated to Denmark before 9/11 to explore whether this would influence our main findings in Study 2. The results from these analyses replicated our main findings, which included Afghans who fled Afghanistan before 9/11 (for multigroup path analysis, see the online supporting information).
} 


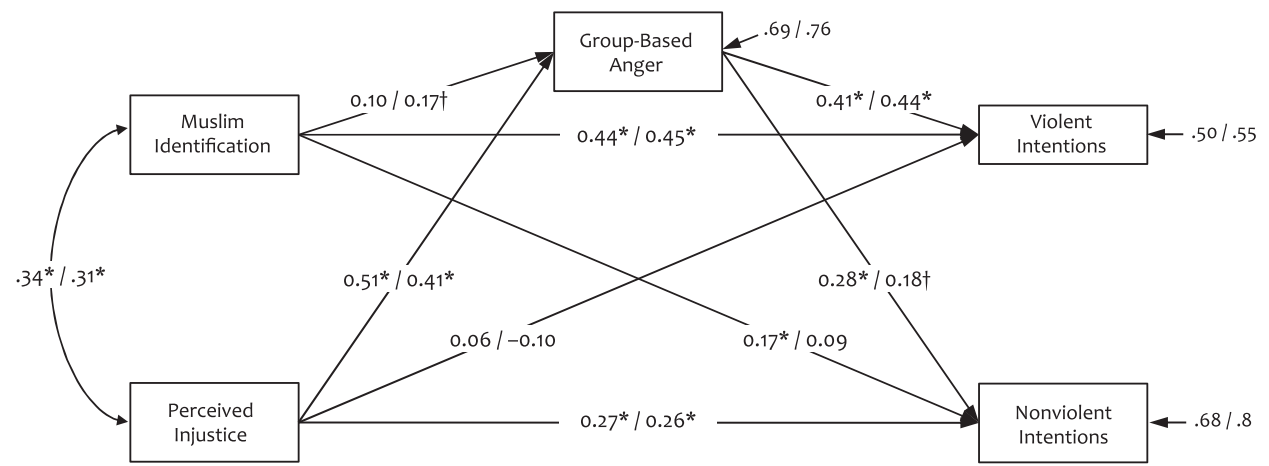

Figure 3. Standardized results of a multigroup path analysis to predict violent and nonviolent intentions to defend Islam and other Muslims. Groups refer to Afghan Danes with no experience versus direct experience of Western foreign policy in Afghanistan. $\dagger p=.09-.11 ; * p<.05$.

effect of perceived injustice on nonviolent intentions among those without personal experience of Western foreign policy $(\beta=0.14,95 \%$ CI $[0.05,0.24])$. No other indirect effects differed from zero by their $95 \%$ CI.

\section{Mean Differences Between Groups With and Without Personal Experience}

Finally, we examined mean differences between the groups with personal experience and noexperience on all variables in our model in a series of ANOVAs (see Figure 4). Participants with no experience of the 2001 invasion scored higher on Muslim identification $(F[1,239]=10.15, p=.002$, $\left.\eta^{2}=.04\right)$, group-based anger $\left(F[1,242]=7.82, p=.006, \eta^{2}=.03\right)$, perceived injustice $(F[1,242]=$ $\left.6.95, p=.009, \eta^{2}=.03\right)$, and violent behavioral intentions $\left.F(1,242)=13.62, p<.001, \eta^{2}=.05\right)$. However, we found no significant difference in nonviolent behavioral intentions between the two groups $\left(F[1,242]=2.98, p=.09, \eta^{2}=.01\right)$.

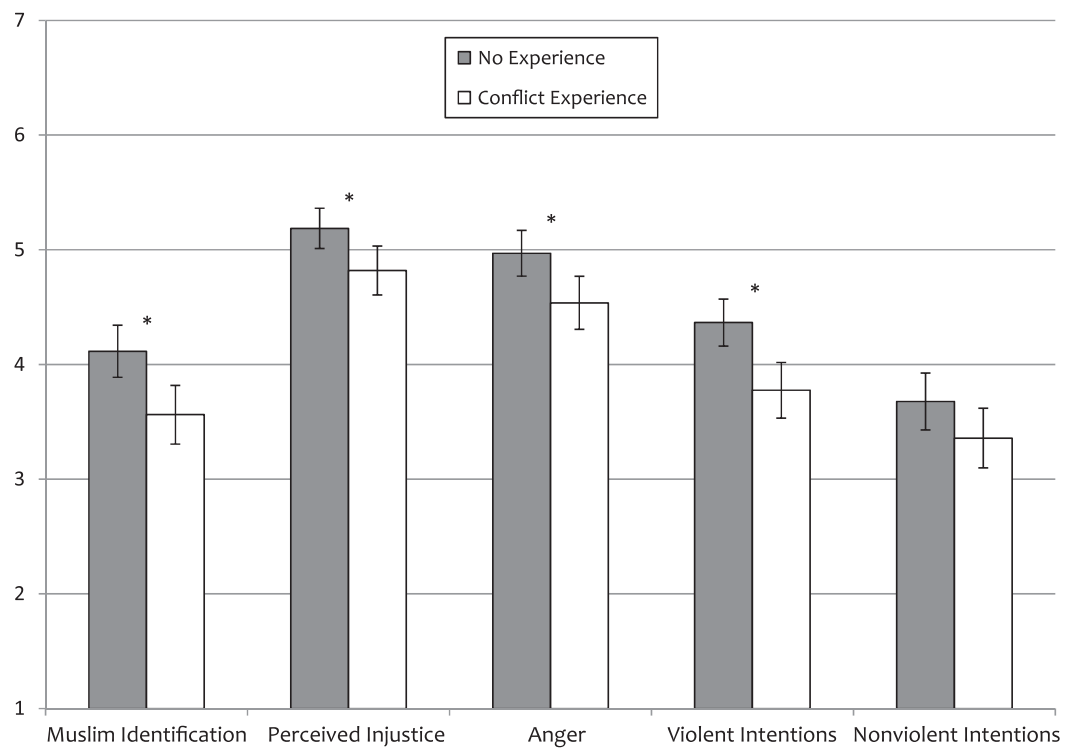

Figure 4. Mean levels of study variables for participants with direct experience of Western foreign policy and versus no experience. Error bars represent $95 \%$ confidence intervals. 


\section{Discussion}

In Study 2, we compared Afghans with and without direct personal experiences of Western foreign policies and military interventions and found no systematic difference in their intentions to commit acts of violence against the West in response to the military occupation of the country. Further, in line with Study 1, native-born Afghans were on average, more strongly identified with Muslims, perceived Western foreign policy as more unjust, reported greater group-based anger, and were more inclined to help Muslims by violent, but not nonviolent, means.

\section{General Discussion}

The present studies tested if victimization-by-proxy processes could explain behavioral intentions among Muslim Danes to use violence in defense of Islam and/or Muslims. To test this, we examined a model based on existing insights on collective action, social identity, and intergroup emotions theories, and we ran multigroup path analyses to compare results of people with, versus without, experience of Western-led war and/or occupation. In Study 1, we compared foreign- and native-born Muslims in Denmark, as a simple and clear-cut proxy of having such experience. We also examined mean differences between native- and foreign-born Muslims for all the variables in the model. In Study 2, we examined the critical hypothesis more directly by focusing on one particular event (the invasion of Afghanistan), and comparing Afghans who did, versus did not, experience it. To our knowledge, these are the first empirical studies that directly test whether key mechanisms in extremism actually operate in vicarious fashion - that is, mimic the effects of direct experience.

Across our two studies, the multi-roup path analyses revealed similar results for the different categories of participants, indicating that inclinations to commit violence in defense of Islam and Muslims, for example, need not be anchored in personally experienced adversity. Instead, vicarious psychological responses can have the same effects. Among participants born in Denmark, personal experience of war, for example, could not possibly account for their Muslim identification, perceptions of global wrongdoings by the West, or subsequent anger and behavioral intentions. Even so, we found these variables to be linked to each other in a similar fashion as they were among participants who had migrated from areas targeted by military interventions or sanctions from the West. As such, these studies provide initial evidence for the victimization-by-proxy perspective.

While discussing the path model, it should be noted, as a caveat, that we did not individually test every single path for differences between the two groups. This also implies that there could be more than mere statistical noise in some of the discrepancies. Still, running tests for individual paths would (ideally) require more knowledge about which ones to focus on in particular (i.e., equivalent to planned contrasts), and they would also be associated with reduced power (see MacCallum et al., 2006). Also, as the constrained models fit the data well, even in absolute terms, a generic model would seem preferable in terms of parsimony, as compared to unique models for native- and foreign-born Muslims.

Beyond the path models, additional results from Study 1 showed that native-born participants were more strongly identified with Muslims, perceived Western foreign policies as more unjust, felt more group-based anger and showed stronger intentions to support Muslims by nonviolent means. In Study 2, we found the same trends. Overall, an important lesson from this inquiry is that the current focus on the relation between Muslims and non-Muslims in the Middle East must be complemented with a stronger focus on the intergroup dynamics within Western societies. Research suggests that ethnic identity has become increasingly salient in the West with public discourse, dividing the population into "us" (typically ethnic Westerners) versus "them" (particularly Muslims; e.g., Massad, 2015). From this perspective, increases in Muslim identification and accompanying group-based emotions might result in feelings of alienation and exclusion. 
These findings are striking given that it is directly opposite to what would be expected from a personal-experience account. Still, this result appears in line with other propositions that second- and third-generation European Muslims particularly struggle with identity crises, feelings of alienation, discrimination, and anger, which make them particularly vulnerable to extremist ideologies (e.g., Lyons-Padilla et al., 2015). Recent studies demonstrate that due to perceived discrimination, Muslims separate more from host societies compared to comparable minorities belonging to other religions, and this effect appears to be greater among second- and third-generation Muslims (Adida, Laitin, \& Valfort, 2015; see also Voas \& Fleischmann, 2012). These studies may hint at least why native-born Muslims strongly identify with Muslims compared to foreign-born Muslims. According to social identity theory, perceived rejection and discrimination lead to higher degree of ingroup identification (Tajfel \& Turner, 1986; see also Ellemers, 1993). This suggests that young Western Muslims, to an increasing degree, perceive and define themselves in terms of their religious affiliation rather than their ethnicity and country of origin (e.g., Roy, 2004). This has also proven to have downstream behavioral consequences. For example, a study investigating the relation between group identification and willingness to participate in political action demonstrated that Moroccan Muslims were more willing to engage in political action when their Muslim identity was made salient (Phalet, Baysu, \& Verkuyten, 2010).

Some argue that second- and third-generation Muslim Europeans, in particular, perceive themselves as disenfranchised and second-class citizens within a society that does not fully accept them. Many may identify as Muslims rather than as Danish or German because of blocked social mobility (Franz, 2007). Based on collective action literature, one can expect that when Muslim immigrants in Denmark compare their circumstances to those of ethnic Danes it is likely to result in an unfavorable comparison, leading to feelings of relative deprivation (Guimond \& Dubé-Simard, 1983). This effect may be particularly strong for native-born Muslims, since they still may see themselves, at least partly, as Danes and part of Denmark, while nonetheless experiencing exclusion and group-based inequality. Such native-born experiences and perceptions could perhaps explain why our native-born participants scored higher on almost all the examined predictors of violent and nonviolent behavioral intentions. As one interviewee put it "many Danes [ethnic Danes] see us as an undesirable element in the Danish society, although we are born and raised here. We speak Danish, we think Danish and we feel Danish, but we will never be 'Danes' in the Danes' eyes. For them we will always be an unwanted and excluded group of people" (Obaidi, 2017; translated from Danish).

It is also possible that the mean differences reflect that foreign-born Muslims find it easier to appreciate how Denmark has offered their families a new home and consequently feel less aggrieved. Either way, there is a need to direct more focus on the precise mechanisms which transform feelings of exclusion into acts of national and international terrorism.

Besides demonstrating victimization-by-proxy processes on Muslim behavioral intentions to commit violence, the current article also speaks to another issue that has been widely debated but empirically understudied. Specifically, many have emphasized the role of emotions, and especially anger, in predicting Islamist extremism. Nevertheless, these accounts are often based on anecdotal evidence (e.g., Atran, 2003). Also, while some have shown that anger is related to nonnormative form of action (e.g., Livingstone et al., 2009), Tausch et al. (2011) have found that the predictive power of anger weakens as the criterion actions become more extreme. In this article, we asked about anger specifically in relation to the foreign policy of Western countries, and we found that anger does indeed predict support for the use of violence. This was the case in all studies.

In line with previous research, Muslim identification had both direct and indirect effects on violent and nonviolent behavioral intentions. The effect of Muslim identification can be seen in the of light of existing cultural tension between Muslims and non-Muslims in Europe as well as Al-Qaeda's pan-Islamic narrative depicting Islam as being under constant threat. These findings are in line with a literature suggesting that perceived group-based injustice is important for predicting collective action 
(e.g., Kawakami \& Dion, 1995). The collective action frame is particularly influential because it appears to resonate strongly with perceived grievances held by Muslims around the world (Lia, 2008), forcing a collective politicized religious identity into awareness. According to Sturmer and Simon (2004), a politicized identity predicts collective action better than a nonpoliticized identity because it taps into a perceived obligation to act on behalf of one's group. As van Zomeren et al. (2008) pointed out, "ultimately, it may not necessarily be social identity or identification per se that prepares people for collective action, but rather the content of social identity" (van Zomeren et al., 2008, p. 522).

Further, it is important to note that the endorsement of violent intentions was low among participants in Study 1 and considerably higher in Study 2. This could be a chance finding, but the size of the difference suggests otherwise (the difference between studies is larger than the significant effects within studies; see Figures 2 and 4). Additional studies would be needed to address the origin of this finding, but importantly it does not seem to influence the interpretation of our main results, regarding differences between people with, versus without, experience of Western military interventions. That is, despite the difference across the studies in terms of endorsement of violence, it is still rather safe to conclude that those with experience from Western interventions are no higher on this variable than those without such experience.

\section{Limitation}

One of the main limitations of our studies is that they rely on Facebook and snowball sampling, which involve nonprobability issues. However, it is also difficult to determine any potential sampling errors with these methods. Nevertheless, Muslim immigrants are a population that is often described as hard to reach. Thus, while this type of sampling has obvious limitations, it is one of the few ways to gain access to this type of population that typically remains invisible in "standard" research. Another potential limitation is that we examined the victimization-by-proxy notion in a context where a tension between non-Muslims and Muslims is particularly salient (Modood, Hansen, Bleich, O'Leary, \& Carens, 2006), and this context might provide (nonvicarious) reasons to express groupbased anger. However, that would not explain the connection with a global Muslim identity and the desire to act on behalf of Muslims in general (rather than striving for a local/national mobilization). Nevertheless, we recognize that our findings may not generalize to contexts where the Muslim versus non-Muslim distinction is less salient and where Muslim identification is less pronounced (indeed, group identification is believed to be a necessary condition for the vicarious processes we discuss here; see, e.g., Pape, 2003). A strong test of the victimization-by-proxy argument would be in a context with a salient Muslim/non-Muslim discourse, but fewer policies explicitly targeting Muslim populations (e.g., in Germany or Sweden).

\section{Closing Reflections}

Belmi, Barragan, Margaret, and Cohen (2015) suggested that situations involving a social identity threat easily generalizes to a global sense that one's group is maltreated in society, which in turn leads to antisocial attitudes, intentions, and disruptive behaviors. Our argument here is similar, but we extend it by noting that perceived mistreatment of one's group not only influences understandings of how a particular society works (in this case Danish society), but also how the world as a whole works. Thus, while we could not argue that experiences in one's closest surroundings are irrelevant, we find it interesting just how far these generalizations seem to go. Specifically, the current findings indicate that Muslims born in Denmark do not merely experience feelings specifically tied to Danish Muslims and mobilization in order to change that society in particular (by violent or nonviolent means) — but they also seem to think, feel, and act on behalf of a global Muslim community. From a social identity perspective, it can be argued that increasingly hostile intergroup interactions between Muslims and non-Muslims may lead to a distinctiveness threat to which Muslim Europeans may respond by 
reasserting their threatened Muslim identity (Brewer, 1991). Because of a heightened sense of Muslim identity, Muslims most likely identify with both the suffering of Muslims in Europe and the suffering of Muslims abroad and, as a result, may feel obliged to act on the basis of this identity. From a perspective stressing direct experience, this makes little sense. However, it fits with the victimization-byproxy argument. Clearly, a "strong" victimization-by-proxy argument that is entirely blind to personal experience seems implausible, but a moderate version-stressing an abstract sense of mistreatment, and potentially based on far-reaching generalizations of observed events, seems more convincing.

\section{ACKNOWLEDGMENTS}

Data collection for the Study 1 was partially funded by Harvard University. The present work benefited from the input of Olivier Roy and Donatella della Porta of European University Institute who commented on the design of the study. We also thank Carlo Agostoni, Jonas Klinck and Rebecca Wolffberg for providing assistance in translating the survey. Correspondence concerning this article should be addressed to Milan Obaidi, Department of Psychology, Uppsala University, Campus Blåsenhus von Kraemers allé 1A and 1C, Room 14:355, Uppsala, Sweden. E-mail: Milan.obaidi@psyk.uu.se

\section{REFERENCES}

Adida, L. C., Laitin, D. D., \& Valfort, M. (2016). Why Muslim integration fails in Christian-heritage societies. Cambridge, MA: Harvard University Press.

Ajzen, I., \& Fishbein, M. (1977). Attitude-behavior relations: A theoretical analysis and review of empirical research. Psychological Bulletin, 84, 888-918.

Atran, S. (2003). Genesis of suicide terrorism. Science, 299, 1534-1539.

Bakker, E. (2006). Jihadi terrorists in Europe: Their characteristics and the circumstances in which they joined the jihad: An exploratory study. Hague, Netherlands: Institute of International Relations Clingendael.

BBC News (2005, September 7). London bomber: Text in full. Retrieved from http://news.bbc.co.uk/2/hi/uk/4206800.stm

Belmi, P., Barragan, R. C., Neale, M. A., \& Cohen, G. L. (2015). Threats to social identity can trigger social deviance. Personality and Social Psychology Bulletin, 41, 467-484.

Branscombe, N. R., Ellemers, N., Spears, R., \& Doosje, B. (1999). The context and content of social identity threat. In N. Ellemers, R. Spears, \& B. Doosje (Eds.), Social identity: Context, commitment, content (2nd ed., pp. 35-58). Oxford, United Kingdom: Blackwell.

Brewer, M. (1991). The social self: On being the same and different at the same time. Personality and Social Psychology Bulletin, 17, 475-482.

Cheung, W. G., \& Rensvold, R. B. (2002) Evaluating goodness-of-fit indexes for testing measurement invariance. Structural Equation Modeling, 9, 233-255.

De Weerd, M., \& Klandermans, B. (1999). Group identification and political protest: Farmers' protest in the Netherlands. European Journal of Social Psychology, 29, 1073-1095.

Doosje, B., Branscombe, N. R., Spears, R., \& Manstead, A. S. R. (1998). Guilty by association: When one's group has a negative history. Journal of Personality and Social Psychology, 75, 872-886.

Doosje, B., Ellemers, N., \& Spears, R. (1995). Perceived intragroup variability as a function of group status and identification. Journal of Experimental Social Psychology, 31, 410-436.

Doosje, B., Loseman, A., \& Van den Bos, K. (2013). Determinants of radicalization of Islamic youth in the Netherlands: Personal uncertainty, perceived injustice, and perceived group threat. Journal of Social Issues, 69, 586-604.

Dumont, M., Yzerbyt, V., Wigboldus, D., \& Gordijn, E. H. (2003). Social categorization and fear reactions to the September 11th terrorist attacks. Personality and Social Psychology Bulletin, 29, 1509-1520.

Ellemers, N. (1993). The influence of socio-structural variables on identity management strategies. In W. Stoebe \& M. Hewstone (Eds.), European review of social psychology (Vol. 4, pp. 27-57). Chichester, United Kingdom: Wiley.

Franz, F. (2007). Europe's Muslims youth: An inquiry into the politics of discrimination, relative deprivation, and identity formation. Mediterranean Quarterly, 1, 89-112.

Gordijn, E. H., Wigboldus, D., \& Yzerbyt, V. Y. (2001). Emotional consequences of categorizing victims of negative outgroup behavior as ingroup or outgroup. Group Processes and Intergroup Relations, 4, 317-326. 
Gordijn, E., H., Yzerbyt, V., Wigboldus, D., \& Dumont, M. (2006). Emotional reactions to harmful intergroup behavior. European Journal of Social Psychology, 36, 15-30.

Grant, P. (2008). The protest intentions of skilled immigrants with credentialing problems: A test of a model integrating relative deprivation theory with social identity theory. British Journal of Social Psychology, 47, 687-705.

Guimond, S., \& Dube-Simard, L. (1983). Relative deprivation theory and the Quebec nationalist movement: The cognition-emotion distinction and the personal-group deprivation issue. Journal of Personality \& Social Psychology, 44(3), 526-535.

Heckathorn, D. D. (1997). Respondent-driven sampling: A new approach to the study of hidden populations. Social Problems, 44, 174-199.

Huntington, S. (1993). The clash of civilizations. Foreign Affairs, 72, 22-49.

Kawakami, K., \& Dion, K. L. (1995). Social identity and affect as determinants of collective action. Theory and Psychology, 5, 551-577.

Khosrokhavar, F. (2005). Suicide bombers. London, United Kingdom: Pluto Press.

Kuppens, T., Yzerbyt, V. Y., Dandache, S., Fischer, A. H., \& van der Schalk, J. (2013). Social identity salience shapes group-based emotions through group-based appraisals. Cognition \& Emotion, 27,1359-1377.

Lewis, B. (1990). The roots of Muslim rage. The Atlantic. Retrieved from http://www.theatlantic.com/magazine/archive/ 1990/09/the-roots-of-muslim- rage/304643/

Lia, B. (2008). Al-Qaida's appeal: Understanding its unique selling points. Perspectives on Terrorism, 2, 1-10.

Lickel, B., Miller, N., Stenstrom, D. M., Denson, T. F., \& Schmader, T. (2006). Vicarious retribution: The role of collective blame in intergroup aggression. Personality and Social Psychology Review, 10, 372-390.

Livingstone, A. G., Spears, R., Manstead, A. S., \& Bruder, M. (2009). Illegitimacy and identity threat in (inter)action: Predicting intergroup orientations among minority group members. British Journal of Social Psychology, 48, 755-775.

Loza, W. (2007). The psychology of extremism and terrorism: A Middle-Eastern perspective. Aggression and Violent Behavior, 12, 141-155.

Lyons-Padilla, S., Gelfand, M, J., Mirahmadi, H., Farooq, M., \& van Egmond, M. (2015). Belonging nowhere: Marginalization and radicalization risk among Muslim immigrants. Behavioral Science \& Policy, 1, 1-12.

MacCallum, R. C., Browne, M. W., \& Cai, L. (2006). Testing differences between nested covariance structure models: Power analysis and null hypotheses. Psychological Methods, 11, 19-35.

Mackie, D. M., Devos, T., \& Smith, E. R. (2000). Intergroup emotions: Explaining offensive action tendencies in an intergroup context. Journal of Personality and Social Psychology, 79, 602-616.

Massad, J. (2015). Islam in liberalism. Chicago, IL: University of Chicago Press.

Modood, T., Hansen, R., Bleich, E., O’Leary, B., \& Carens, J. H. (2006), The Danish cartoon affair: Free speech, racism, Islamism, and integration. International Migration, 44, 3-62.

Mummendey, A., Kessler. T., Klink, A., \& Mielke, R. (1999). Strategies to cope with negative social identity: Predictions by social identity theory and relative deprivation theory. Journal of Personality and Social Psychology, 76, $229-245$.

Muthén, L. K., \& Muthén, B. O. (2012). Mplus user's guide (7th ed.). Los Angeles, CA: Muthén \& Muthén.

Nesser, P. (2006). Jihadism in Western Europe after the invasion of Iraq: Tracing motivational influences from the Iraq War on Jihadist terrorism in Western Europe. Studies in Conflict \& Terrorism, 29, 323-342.

Obaidi, M. (2017). An investigation of social and psychological factors that contribute to the motivations behind the radiclaization of first, second and third generations of Muslim Danes with a migrant background. Manuscript in preparation.

Pape, R. A. (2003). The strategic logic of suicide terrorism. American Political Science Review, 97, 343-361.

Pape, R. A. (2006, November 1). Suicide terrorism and democracy: What we've learned since 9/11. Policy Analysis, $1-18$.

Phalet, K., Baysu, G., \& Verkuyten, M. (2010). Political mobilization of Dutch Muslims: Religious identity salience, goal framing, and normative constraints. Journal of Social Issues, 66, 759-779.

Preacher, K. J., \& Coffman, D. L. (2006, May). Computing power and minimum sample size for RMSEA [Computer software]. Retrieved from http://quantpsy.org/

Reuter, C. (2015, April 18). The terror strategist: Secret files reveal the structure of Islamic state. der Spiegel online. Retrieved from http://www.spiegel.de/international/world/islamic-state-files-show-structure-of-islamist-terror-groupa-1029274.html

Roy, O. (2004). Globalized Islam, the search for a new Ummah. London, United Kingdom: Hurst.

Schmid, A., P. (2013). Radicalisation, de-radicalisation, counter-radicalisation-A conceptual discussion and literature review. The Hague, The Netherlands: International Center for Counter-Terrroism. 
Sciolino, E. (2005, July 8). The ghosts of Madrid stalk the bloodied streets of London. International Herald Tribune.

Sidanius, J., Kteily, N., Levin, S., Pratto, F., \& Obaidi, M. (2015). Support for asymmetric violence among Arab populations: The clash of cultures, social identity, or counter-dominance? Group Processes and Intergroup Relations, 19, 1-17.

Silke, A. (2004). Research on terrorism: Trends, achievements and failures. London, United Kingdom: Fran Cass.

Simon, B., et al. (1998). Collective identification and social movement participation. Journal of Personality and Social Psychology, 74, 646-658.

Smith, E. R. (1993). Social identity and social emotions: Toward new conceptualizations of prejudice. In D. M. Mackie \& D. L. Hamilton (Eds.), Affect, cognition, and stereotyping: Interactive processes in group perception (pp. 183196). Oxford, United Kingdom: Blackwell.

Smith, E. R., \& Mackie, D. M. (2015). Dynamics of group-based emotions: Insights from intergroup emotions theory. Emotion Review, 7, 349-354.

Smith, E. R., Seger, C. R., \& Mackie, D. M. (2007). Can emotions be truly group level? Evidence regarding four conceptual criteria. Journal of Personality and Social Psychology, 93, 431-446.

Smith, J. H., Pettigrew, T. F., Pippin, G. M., \& Bialosiewicz, S. (2012). Relative deprivation: A theoretical and meta-analytic review. Personality and Social Psychology Review, 16, $203-332$.

Sturmer, S., \& Simon, B. (2004). The role of collective identification in social movement participation: A panel study in the context of the German gay movement. Personality and Social Psychology Bulletin, 30, 263-277.

Tajfel, H., \& Turner, J. C. (1979). An integrative theory of intergroup conflict. In W. G. Austin \& S. Worchel (Eds.), The social psychology of intergroup relations (pp. 33-47). Monterey, CA: Brooks-Cole.

Tajfel, H., \& Turner, J. C. (1986). The social identity theory of intergroup behavior. In S. Worchel \& W. G. Austin (Eds.), Psychology of intergroup relations (pp. 7-24). Chicago, IL: Nelson-Hall.

Tausch, N., Becker, J. C., Spears, R., Christ, O., Saab, R., Singh, P., \& Siddiqui, R. N. (2011). Explaining radical group behavior-developing emotion and efficacy routes to normative and nonnormative collective action. Journal of Personality and Social Psychology, 101, 129-148.

Turner, J. C., Hogg, M. A., Oakes, P. J., Reicher, S. D., \& Wetherell, M. S. (1987). Rediscovering the social group: A self-categorization theory. Oxford, United Kingdom: Basil Blackwell.

Voas, D., \& Fleischmann, F. (2012). Islam moves West: Religious change in the first and second generations. Annual Review of Sociology, 38, 525-545.

Wagemakers, J. (2008). Framing the threat to Islam: Al-Wala'Wa Al-Bara' in Salafi discourse. Arab Studies Quarterly, $30,1-22$.

Wright, S. C., Taylor, D. M., \& Moghaddam, M. F. (1990). Responding to membership in a dis disadvantaged group: From acceptance to collective protest. Journal of Personality and Social Psychology, 58, 994-1003.

Yzerbyt, V., Y., Dumont, M., Wigboldus, D., \& Gordijn, E. (2003). I feel for us: The impact of categorization and identification on emotions and action tendencies. British Journal of Social Psychology, 42, 533-549.

van Zomeren, M., Postmes, T., \& Spears, R. (2008). Toward an integrative social identity model of collective action: A quantitative research synthesis of three socio-psychological perspective. Psychological Bulletin, 134, 504-535.

\section{SUPPORTING INFORMATION}

Additional supporting information may be found in the online version of this article at the publisher's website:

Table S1. Items, Reliabilities, Mean Levels and Standard Deviations for Muslim Identification, Perceived Injustice, Group-Based Anger, Violent and Nonviolent Behavioral Intentions for Native- and Foreign-Born Muslims (Study 1a and 1b) and Afghans Without and With Direct Personal Experience of Western Foreign Policy (Study 2)

Path Analysis Study 2 With Identical Items as in Study 1

Figure S1. Standardized Results of a Multigroup Path Analysis to Predict Violent and Nonviolent Intentions to Defend Islam and Other Muslims Among Afghan Danes Using Two Violent Behavioral Intention Items for Violence From Study 1

Results: Preliminary Path Analyses

Results: Path Model Predicting Violent and Nonviolent Behavioral Intentions

Results 